\title{
A CRISE DA DEMOCRACIA LIBERAL E A OFENSIVA POPULISTA: o Impacto do Sistema Interamericano de Direitos Humanos
}

\author{
Flávia Piovesan \\ Pontifícia Universidade Católica de São Paulo. São Paulo/SP, Brasil. http://lattes.cnpq.br/1701611968664709. \\ https://orcid.org/0000-0001-9441-8376. fpiovesan@hotmail.com

\section{Gabriel Pinho Brochado} \\ Autor correspondente. Pontifícia Universidade Católica de São Paulo (PUC/SP). http://lattes.cnpq.br/1947856800251635. \\ https://orcid.org/0000-0001-8972-6614. gabrielpinhob@gmail.com
}

RESUMO

Objetiva este artigo enfocar a crise da democracia liberal com a ascensão de movimentos populistas e o seu risco democrático, sob a perspectiva do sistema interamericano. Para tanto, foram analisados três julgados emblemáticos da Corte Interamericana de Direitos Humanos, identificando dois importantes aspectos: a tendência populista em atacar a independência judicial e o princípio da separação de Poderes; e a essencialidade da atuação conjunta dos atores institucionais internos e internacionais para a necessária proteção dos princípios básicos democráticos, considerando, sobretudo, o impacto do sistema interamericano de proteção dos direitos humanos.

Palavras-chave: democracia liberal; populismo; sistema interamericano de proteção dos direitos humanos.

\section{THE CRISIS OF LIBERAL DEMOCRACY AND THE POPULIST OFFENSIVE: THE IMPACT OF THE INTER-AMERICAN SYSTEM OF HUMAN RIGHTS}

\section{ABSTRACT}

This article aims to approach the crisis of liberal democracy with the rise of populist movements and their risk for democracy, from the perspective of the inter-american system. For this purpose, we analyzed three judgments of the Inter-American Court of Human Rights, identifying two important aspects: the populist tendency to attack judicial independence and the principle of separation of powers; and the essentiality of joint action by internal and international institutional actors in the protection of basic democratic principles, considering the impact of the Inter-American System of Human Rights.

Keywords: liberal democracy; populism; inter-american system of human rights. 


\section{Democracia}

Humanos e

\section{INTRODUÇÃO}

Há uma perigosa tendência que ronda a América Latina - o populismo. Iniciamos este texto ressaltando este movimento político que disparou por todo o globo, sobretudo no decorrer do século 21. A crise da democracia liberal, mais do que um momento que faz refletir sobre os verdadeiros significados de democracia e de liberalismo, representa um novo marco político na história da humanidade.

Até então inquestionável, a democracia liberal era vista com bons olhos pela ampla maioria dos cidadãos, que enxergavam esse modelo de democracia como inacabado, mas como o único possível para o bom desenvolvimento da sociedade e suas forças produtivas. $A$ memorável frase proferida por Winston Churchill durante o seu discurso na Câmara dos Comuns, em 1947, "a democracia é a pior forma de governo, com exceção de todas as demais", já não é tão inquestionável na mente dos indivíduos.

Teorias políticas à parte, a crise de legitimidade do atual sistema político, em âmbito mundial, tem fomentado um pensamento que questiona os clássicos modelos de sistemas político-econômicos. Sem ser necessariamente atrelado às tradicionais tipologias políticas binárias "esquerda e direita", o fenômeno do populismo é reflexo de uma democracia liberal já não mais unânime mundialmente. $\mathrm{O}$ que alguns estudiosos costumam denominar como democracia iliberal, entretanto, é alvo de questionamentos por parte da doutrina, uma vez que não seria possível denominar como democrático um sistema que desfigura os traços democráticos, escancarando apenas o aspecto iliberal.

Paralelamente, o desenvolvimento do autoritarismo pelas vias democráticas implica uma séria ameaça aos direitos humanos conquistados historicamente pela sociedade no plano internacional. Não é difícil constatar direitos civis sendo limitados e restringidos, tais como o direito à liberdade de expressão, o direito à manifestação e o direito à livre-associação. Nesse terreno, por seu próprio fundamento, as Comissões e Cortes internacionais de direitos humanos também se tornam alvo de governos populistas.

Desse modo, o que se objetiva com este artigo é compreender como a crise de representatividade das instituições do Estado Democrático de Direito possibilita e estimula o desenvolvimento de movimentos, partidos e lideranças populistas, especialmente no eixo Sul global, e como esse evento político desafia os direitos humanos, com ênfase no impacto do sistema interamericano de proteção de direitos humanos, realçando a integridade e a legitimidade da Comissão Interamericana de Direitos Humanos (CIDH) e da Corte Interamericana de Direitos Humanos.

Para tanto, em um primeiro momento, buscamos contextualizar brevemente o cenário de crise da democracia liberal. Este cenário é compreendido enquanto expressão da crise econômica que avançou sob o sistema econômico globalizado, bem como da perda de legitimidade das instituições democráticas, especialmente representativas.

É a partir desse marco contextual que, aqui, se ambiciona conceituar laconicamente esse perigoso fenômeno que renasce com novas características no século 21. Como surge? Quais são as suas principais características? Como os populistas ameaçam os direitos humanos e os atores internacionais de proteção?

Por fim, o artigo busca analisar a responsabilidade dos atores internacionais objetivando identificar como eles atuam e podem atuar ante a esses ataques. Nesse ponto, propomos 
identificar esses atores como de extrema relevância no cenário de proteção e combate aos ataques da política populista, sendo de absoluta importância a atuação conjunta dos atores nacionais e internacionais na proteção da democracia institucional. Neste sentido, qual tem sido o impacto do sistema interamericano na salvaguarda dos direitos humanos, da democracia e do Estado de Direito na região?

São estas as questões centrais que inspiram o presente artigo.

\section{A CRISE DA DEMOCRACIA LIBERAL}

A democracia apresentava-se enquanto um sistema preferível de governo, ainda que imperfeito e inabalado. Era comum identificar os discursos de que esse era o único sistema possível, o mais avançado e aceito pela sociedade. O que se observa, entretanto, é uma tendência justamente oposta: os governados enxergam-se cada vez mais distantes dos governantes; as instituições já não os representam e não dão respostas imediatas aos seus anseios.

No Brasil, o aumento de $\mathrm{R} \$ \mathbf{0 , 2 0}$ no preço da passagem de ônibus em diferentes cidades do país - inicialmente em São Paulo, posteriormente por quase todos os grandes municípios - desencadeou as maiores manifestações de massas desde o impeachment do ex-presidente Fernando Collor. "Não são só por R\$ 0,20" - entoavam os manifestantes em 2013 em referência ao aumento nas tarifas -, mas, sim, por toda a desigualdade social. Eram correntes os cartazes que exigiam educação, saúde e transporte de qualidade - ou padrão Fifa, em referência à Copa do Mundo realizada no país no ano seguinte.

As Jornadas de Junho de 2013 - alcunha como ficou conhecida a série de manifestações que assolaram o Brasil naquele ano - levaram milhões de jovens e trabalhadores às ruas pelo país inteiro, escancarando a insatisfação popular e a truculência policial.

Seguindo a linha defendida por Manuel Castells, o que se percebe de todo esse processo é uma crise muito mais profunda e ampla do que as que já foram observadas nas últimas décadas: é "a ruptura da relação entre governantes e governados" (CASTELLS, 2018, p. 7). A ruptura nada mais é do que a crise de legitimidade política-institucional. Acima de todas as outras, a crise da democracia liberal revela um descontentamento com as instituições e os seus representantes, ou seja, é fruto de várias crises que, conjuntamente, refletem um único denominador comum: a democracia liberal.

Faz-se necessário, neste aspecto, estabelecer quais são os conceitos adotados para a compreensão da democracia liberal e sua atual crise. O cientista político alemão Yascha Mounk, em sua obra $O$ povo contra a democracia: por que nossa liberdade corre perigo e como salvá-la, estabelece um conjunto de definições que contribui para a abordagem desses elementos. Inicialmente, Mounk explica que "a democracia é um conjunto de instituições eleitorais com poder de lei que traduz as opiniões do povo em políticas públicas" (2019, p. 44). Logo, a democracia está diretamente ligada à compreensão de tradução da opinião do povo em política pública por meio das instituições eleitorais. $O$ referido autor continua explicando que "as instituições liberais efetivamente protegem o Estado de direito e garantem os direitos individuais para todos os seus cidadãos" (MOUNK, 2019, p. 44). 


\section{Democracia}

Humanos e

A partir das definições utilizadas por Mounk, a democracia liberal é "um sistema político ao mesmo tempo liberal e democrático - um sistema que tanto protege os direitos individuais como traduz a opinião popular em políticas públicas" (2019, p.44).

Retornando ao contexto brasileiro, a promulgação da Emenda Constitucional no 95, por exemplo, em um cenário no qual os $10 \%$ mais ricos ganham 17,6 vezes mais que os $40 \%$ mais pobres, concentrando mais de $40 \%$ da riqueza nacional ${ }^{1}$, em que o desemprego atinge a taxa de $11 \%$ no último trimestre de 2019 , representando mais de 11 milhões de pessoas, e que o trabalho informal representa mais de $40 \%$ da população ocupada ${ }^{2}$, apenas reforçou o descontentamento dos governados com o sistema liberal, especialmente entre aqueles mais atingidos pelas medidas de austeridade, transformando-o num fator nuclear. Na raiz da crise de legitimidade política, o que se encontra em maior evidência é justamente a crise financeira. É a crise econômica, aliada à crise de emprego, que faz aprofundar as desigualdades e ressaltar a necessidade de mudanças institucionais aos olhos dos governados.

Manuel Castells (2018, p. 20) explica que

Foi, na realidade, a crise de um modelo de capitalismo, o capitalismo financeiro global, baseado na interdependência dos mercados mundiais e na utilização de tecnologias digitais para o desenvolvimento de capital virtual especulativo que impôs sua dinâmica de criação artificial de valor à capacidade produtiva da economia de bens e serviços.

O modelo econômico neoliberal fomentou um processo de globalização das economias estatais, gerando uma interdependência dos mercados mundiais. Essa perda generalizada de uma soberania econômica reflete no enfraquecimento da soberania política. Por sua vez, as políticas de austeridade, promovidas pelas grandes potências mundiais, revelam a falácia da ideologia neoliberal que, até então, se comportava de modo a repudiar a intervenção do Estado nos mercados.

A proteção estatal dos grandes empresários e políticos, em razão das emergências sociais, os cortes em direitos sociais e os altos índices de desemprego, canalizam a insatisfação popular em grandes contramovimentos que enxergam na imagem dos governantes os seus inimigos centrais, uma vez que protegem uma minoria populacional que detém a maior parte das riqueza nacional perante os mais afetados pela crise. ${ }^{3}$ Nas palavras de Castells $(2018$, p. 12), "se for rompido o vínculo subjetivo entre o que os cidadãos pensam e querem e as ações daqueles a quem elegemos e pagamos", o resultado passa a ser justamente o que ele denomina de "crise de legitimidade política".

A fim de elucidar a questão, Karl Polanyi (apud DELLA PORTA, 2019, p. 59), em sua obra A grande transformação, descreveu a crise do neoliberalismo em um duplo movimento no

G1. No Brasil, $10 \%$ mais ricos ganham cerca de 17,6 vezes mais que os $40 \%$ mais pobres, aponta IBGE. Disponível em: https://g1.globo.com/economia/noticia/2018/12/05/no-brasil-10-mais-ricos-ganham-cerca-de-176-vezes-mais-que-os40-mais-pobres-aponta-ibge.ghtml. Acesso em: 6 jan. 2020.

2 FIESP. Desemprego fica em 11\% em dezembro, mas ainda atinge 11,6 milhões, diz IBGE. Disponível em: https://www.fiesp. com.br/sietex/noticias/desemprego-fica-em-11-em-dezembro-mas-ainda-atinge-116-milhoes-diz-ibge/. Acesso em: 18 fev. 2020.

3 Mounk destaca que, "Embora a desigualdade global tenha diminuído porque os países pobres têm crescido muito mais rápido do que os ricos, a desigualdade em praticamente todas as sociedades - tanto as economias mais estagnadas do Ocidente afluente como as economias mais dinâmicas do Sul mundial - aumentou de forma visível” (2019, p. 55). 
avanço do sistema capitalista: "primeiro a sociedade vivencia um estímulo à mercantilização, seguida pela emergência de contramovimentos que buscam a seguridade social".

Estes mesmos contramovimentos podem apresentar características distintas. Em muitos cenários vislumbra-se contramovimentos de cunho progressista. São verdadeiros atores sociais que visam à proteção dos direitos sociais afetados pela crise neoliberal. A crise de legitimidade política expressou-se na desconfiança dos diferentes setores da sociedade com as instituições tradicionais do Estado Democrático de Direito, seja porque elas não refletiam as suas vontades e não escutavam os seus anseios, seja porque vislumbravam que as instituições estavam totalmente atreladas aos interesses do grande capital dominante.

Donatella Della Porta argumenta que, embora sejam tomadas pelo enfoque da soberania nacional contra as políticas de austeridade, os contramovimentos progressistas defendiam direitos políticos e sociais como direitos humanos, ou seja, lutavam contra a centralização do poder político e econômico enquanto direitos básicos e imprescindíveis à vida em sociedade. Assim,

Em certo sentido, os protestos contra austeridades eram conservadores, já que pediam a restauração de direitos perdidos e denunciavam veementemente a corrupção da democracia. Porém também olharam para a frente, unindo o interesse por direitos sociais com a expectativa de inclusão cultural (DELLA PORTA, 2019, p. 67).

Esses movimentos não são simplesmente contra a democracia, mas, sim, contra a sua degeneração. As suas experiências, inclusive conforme observa-se das Jornadas de Junho, portanto, questionaram diretamente a democracia representativa, repensando a democracia institucional posta, contribuindo para a elaboração e o desenvolvimento de um modelo democrático participativo e deliberativo.

Ao mesmo tempo, entretanto, que contramovimentos (ou movimentos) podem ser progressistas e respaldados sobre uma visão inclusiva, a crise da democracia liberal pode refletir no surgimento de contramovimentos regressivos, que dão a impressão de estarem lutando em solidariedade aos marginalizados e segregados pelas políticas de austeridade, mas, em verdade, lutam apoiados pela elite econômica e política (DELLA PORTA, 2019, p. 71).

Os contramovimentos regressivos são a faceta mais assombrosa da crise da democracia liberal. Aqui, não se busca lutar contra a degeneração da democracia, mas contra a própria democracia. Esses contramovimentos sustentam-se a partir de uma crise identitária-cultural alavancada pelo processo de globalização. São movimentos pautados pelo atual tripé ultranacionalista contemporâneo: $i$. o nacionalismo xenófobo; ii. o nacionalismo cultural; e iii. o nacionalismo autoritário. Juntos, os pilares do tripé ultranacionalista contemporâneo convergem em discursos de ódio que reivindicam uma soberania identitária e cultural.

O século 21 está marcado por ser a "era dos radicalismos" versus a "sociedade de direitos". É lançada a tensão entre o globalismo e os localismos ultranacionalistas.

\section{A ASCENSÃO DO POPULISMO}

A partir da fadiga da democracia liberal, com o avanço de contramovimentos regressivos, o terreno da democracia tornou-se extremamente fértil ao desenvolvimento de líderes que prometem solucionar todos os problemas de crise econômica, crise de representativida- 
de e, principalmente, crise identitária-cultural. Isso não é novo. A novidade do atual declínio democrático é que, enquanto em boa parte do século 20 a democracia foi alvo de ataques pela ruptura brusca com a ordem institucional via a tomada armada do poder, com o fim da guerra fria - o que o cientista político Francis Fukuyama denominou de "o fim da história" os populistas autoritários não usaram mais armas ou tanques de guerra para alcançar o poder: atualmente, a sua ascensão se dá pela via eleitoral. "Democracias podem morrer não nas mãos de generais, mas de líderes eleitos" (LEVITSKY; ZIBLATT, 2018, p. 15).

A ruptura democrática encarada pela via eleitoral fica mais perceptível quando passamos a olhar para as urnas - sobretudo em momentos de crise econômica ou de representatividade - enquanto instrumentos de tradução dos anseios populares. Isto é, em momento eleitoral as urnas transformam-se na voz do povo, que dá a sua opinião sobre os líderes eleitos e suas políticas. Ocorre que as eleições foram transformadas em uma via de saída da própria democracia, ao invés de serem utilizadas como meio de correção e debate político do sistema democrático (APPADURAI, 2019, p. 27-28).

Assim, sob o discurso do tripé ultranacionalista, os movimentos regressivos desenvolvem-se reivindicando um nacionalismo xenófobo, cultural e autoritário, apresentando-se enquanto alternativas à democracia liberal e buscando nas urnas a sua chance de alcançar o poder e pôr em prática o seu programa de ruptura com o sistema democrático.

É perceptível da reivindicação dos contramovimentos regressivos que o populismo emerge com um viés de democracia representativa. $O$ discurso populista é enraizado pela representatividade. A figura do líder populista, ou leadership, é imprescindível para a caracterização desse fenômeno. Ao debruçar-se sobre a temática do populismo, no livro What is Populism? Jan-Werner Müller (2017) identificou uma série de características comuns que acompanham os diferentes movimentos populistas.

Primeiramente, destaca o autor, o populismo é sempre crítico das elites (MÜLLER, 2017). Ainda que não seja essa uma condição suficiente para classificar um contramovimento (ou movimento) ${ }^{4}$ enquanto populista, essa é uma condição imprescindível. É, entretanto, ainda mais certo que, não obstante eles finjam prestar solidariedade com os $99 \%$ da população, os populistas acabam desfrutando do apoio do poderoso $1 \%$ restante que já detém o poder político e econômico.

Em segundo lugar, o populismo, além de ser antielitista, é também antipluralista (MÜLLER, 2017). O populismo não aceita outra visão política. O leadership é o único e verdadeiro representante dos interesses do povo; o único eivado da verdadeira moral que rege todo o movimento. Logo, não há outra oposição legítima que não a exercida por ele. Até porque, se legítima fosse, faria parte do movimento.

Seguindo essa mesma linha de raciocínio, toda a oposição ao seu governo, quando consegue alcançar o poder institucional, também não é uma oposição legítima, uma vez que qualquer crítica ao movimento populista seria uma crítica ao próprio povo e, por consequência, imoral e ilegítima.

Nesse cenário, usaremos essas duas palavras enquanto sinônimas. Isso porque, como já ressaltamos anteriormente, indicamos que esses movimentos se tratam, na realidade, de contramovimentos à democracia liberal, ainda que progressivos ou regressivos. 


\section{Democracia}

Além disso, Müller explica que esse antipluralismo é sempre moral, o que leva a conceber uma característica identitária do movimento. O populismo é sempre um movimento identitário, embora nem todas as políticas identitárias sejam populistas. Em outras palavras, o leadership concebe ao movimento definição sobre quem é o verdadeiro povo e quais são os seus interesses. Nas palavras de Müller (2017), "é esta reivindicação nuclear do populismo: só uma parte do povo é realmente o povo".

O povo, portanto, é a locomotiva do movimento, mas a sua concepção é moral e infalível, e sendo este povo uma definição moral, apenas uma parte do povo é verdadeiramente o povo, cabendo única e exclusivamente ao populista estabelecer esse recorte, por ser ele o seu único representante. ${ }^{5}$

O cientista político Kenneth Roberts (apud DELLA PORTA, 2019, p. 72) explica que "o populismo normalmente envolve a subjetividade popular pelas personalidades dominantes que controlam os canais, ritmos e formas organizacionais da mobilização social". Vale dizer, o leadership é o fio condutor da subjetividade popular, definindo o verdadeiro povo. Então, ainda que o movimento pareça falar em representação dos anseios populares, o que a realidade demonstra, em verdade, é que o discurso do populista é ligado ao vínculo plebiscitário. Trata-se de uma espécie de vínculo plebiscitário invertido à lógica tradicional: não se fala em nome do povo, mas, sim pelo povo.

O leadership não está preocupado em democratizar as instituições e dar verdadeiramente "voz", envolvendo os mais diversos atores sociais no processo decisório: seja porque o povo que ele representa é apenas o povo que ele escolheu representar e que o ostenta de plena moralidade, seja porque a voz do leadership é a única verdadeiramente a ecoar pelo movimento.

Appadurai (2019, p. 25), ao tecer uma relação mais simplificada entre os líderes dos atuais regimes populistas autoritários, sustenta que estes têm em comum as seguintes características:

(...) a admissão de que nenhum deles pode de fato controlar a economia de seus países, refém de investidores estrangeiros, acordos globais, finanças transnacionais, mão de obra móvel e capital de modo geral. Todos eles prometem a purificação da cultura nacional como via de poder político global. Todos são simpáticos ao capitalismo neoliberal, cada um com a própria versão de como fazê-lo funcionar (...).

Por sua vez, quando chegam ao poder, enquanto únicos legítimos representantes do povo, do verdadeiro povo, os populistas possuem três maneiras distintas e costumeiras de se comportar: a primeira, é o que Müller (2017) denomina de "colonização do Estado"; a segunda seria o "clientelismo de massas" e "legalismo discriminatório"; e, por fim, a repressão sistemática da sociedade civil.

A primeira medida adotada pelos populistas, denominada colonização do Estado, é materializar um Estado "a sua imagem e semelhança". Uma vez no poder, o leadership busca eliminar todo o tipo de entrave à sua política. Tenta utilizar a própria característica democrática

"Esse porta-voz do povo é o populista - e ele não se cansa de repetir isso" (MOUNK, 2019, p. 61). 
das instituições para conferir legitimidade ao seu governo, ao mesmo tempo em que tenta aparelhar estas instituições com a sua linha política.

No que se refere ao clientelismo de massas e ao "legalismo discriminatório", a troca de favores entre governante e governados, favores materiais e imateriais, seria realizada "abertamente e com uma justificação moral pública, visto que para eles [os populistas] apenas alguns membros do povo são realmente o povo e merecedores portanto do apoio do que é, por direito próprio, o seu Estado" (MÜLLER, 2017). O mesmo entendimento aplica-se ao legalismo discriminatório, posto que nesse movimento apenas o verdadeiro povo pode desfrutar da proteção das leis.

Em relação à repressão sistemática da sociedade civil, conforme explica Appadurai (2019, p. 25), os populistas "buscam converter poder brando em poder coercitivo. E nenhum deles tem restrições quanto a reprimir minorias e dissidentes, abafar a liberdade de expressão ou usar as leis para sufocar os oponentes". Nesse aspecto, o fenômeno do populismo merece ainda mais atenção. É o que Mounk (2019, p. 65) defende como "a guerra contra as instituições independentes". Ao constatarem que essas instituições independentes têm legitimidade de representação sob diferentes segmentos da sociedade, os populistas tendem a se sentir ameaçados - afinal, eles [os populistas] são os únicos representantes do povo, o legítimo porta-voz dos seus interesses e de suas opiniões. Logo,

Diante da pretensão populista de ser a única representante da vontade popular, a política logo se torna uma luta existencial entre o povo real e seus inimigos. (...) Com o tempo, passam a considerar toda voz dissonante como traição e concluem que qualquer instituição que fique em seu caminho é uma deturpação ilegítima da vontade do povo. Ambas precisam ser erradicadas. Resta apenas o capricho do populista (MOUNK, 2019, p. 66).

O modo autoritário como os populistas tendem a exercer o seu governo levanta a discussão quanto à natureza do populismo. Muitos estudiosos afirmam que o populismo é uma democracia iliberal. Sustentam que, uma vez que praticam as eleições periodicamente, seriam democracias, ainda que não observem direitos humanos (repressão sistemática da sociedade civil) ou o próprio sistema de freios e contrapesos (colonialismo de Estado).

Mounk (2019), por exemplo, explica que é necessário admitir traços democráticos nos movimentos populistas: “(...) os populistas de hoje alegam que estão procurando aprofundar os elementos democráticos de nosso atual sistema. Isso é importante" (p. 73), destaca o autor; e afirma: "Longe de querer abolir a democracia, eles estão impacientes para ver a vontade popular remodelar o país à sua imagem" (p. 54).

A própria prática dos seus três modos de governo, em nossa visão, entretanto, já afasta o conceito de democracia. Esse ânimo democrático, que supostamente os populistas levantam, na realidade é o ânimo democrático do próprio leadership, único porta-voz do povo, do seu povo. Alinhamo-nos à visão de Jan-Werner Müller ao defender que o populismo não é uma democracia iliberal. Pelo contrário, o populismo distorce o processo democrático; ele danifica a própria democracia. Nesse sentido, Müller (2017) esclarece que 
O jogo está viciado, mas não é impossível - ainda - ganhar uma eleição na base da crítica dos populistas no poder. Talvez, então, uma designação como "democracia defeituosa" fosse mais apropriada.

Em contexto de "democracia defeituosa", não são poucos os ataques aos direitos humanos praticados pelos populistas ao "não povo". É muito mais fácil atuar no ataque aos direitos quando não há liberdade de expressão para denunciá-los. A censura aos meios de comunicação, diminuindo a liberdade de imprensa, é medida que se demonstra importante para a prática do projeto populista. Afinal, o maior empecilho enfrentado pelo leadership na instituição de suas políticas é justamente a transparência e o conhecimento científico, que não possuem condições de enfrentar os questionamentos por meio da argumentação ou do debate, recoIhendo-se ao plano do seu poder institucional e do apoio popular.

Então, seja por meio da repressão ou por intermédio da censura, as liberdades individuais emergem como direitos constantemente atacados pelos leaderships. Inclusive, Levitsky e Ziblatt (2018), baseados no trabalho elaborado pelo cientista político Juan Linz, desenvolveram um conjunto de sinais de alerta que podem contribuir na identificação de um regime populista autoritário. Em um deles, os autores defendem que os regimes populistas têm propensão a restringir as liberdades civis de oponentes, inclusive a dos meios de comunicação. Expressam, então, os seguintes questionamentos:

Apoiaram leis ou políticas que restrinjam liberdades civis, como expansões de leis de calúnia e difamação ou leis que restrinjam protestos e críticas ao governo ou certas organizações cívicas ou políticas?

Ameaçaram tomar medidas legais ou outras ações punitivas contra seus críticos em partidos rivais, na sociedade civil ou na mídia?

Elogiaram medidas repressivas tomadas por outros governos, tanto no passado quanto em outros lugares do mundo? (LEVITSKY; ZIBLATT, 2018, p. 33).

São questionamentos que expõem traços autoritários dos pensamentos do populista. Não restam dúvidas que em governos populistas os direitos humanos são fragilizados, alvos de fortes ataques e merecem as devidas preocupações pelos agentes democráticos. Nesse sentido, cabe ressaltar que a ofensiva se volta tanto aos atores internos quanto, também, aos atores internacionais que atuam na proteção de direitos humanos.

No âmbito nacional, por exemplo, é comum presenciar investidas contra a autonomia da Corte Constitucional nacional. A colonização do Estado pode passar pelo aumento do número de ministros, a fim de se ter uma maioria na Corte, ou pela própria aposentadoria compulsória dos ministros mais progressistas e contrários ao regime populista. Até mesmo o descumprimento das decisões emitidas pela Corte Constitucional, deslegitimando a competência do Poder Judiciário, é um ataque que, mais do que uma simples guerra entre Poderes, representa uma verdadeira ruptura com o princípio da separação dos Poderes e com o sistema de pesos e contrapesos.

No plano internacional - no qual, aqui, buscamos nos ater - a ofensiva é contra os atores que fiscalizam a proteção dos direitos humanos. O leadership, quando verifica que os agentes do sistema internacional de proteção dos direitos humanos são contrários aos seus interesses, com uma atuação crítica e contrária aos seus atos, usa a pauta identitária para 
classificá-los como inimigos, contrários aos verdadeiros interesses do povo (leia-se, mais uma vez, interesses do populista). Os populistas tentam desqualificá-los, acusando-os de não serem verdadeiramente democráticos, mas, sim de atuarem como instrumento de vontade dos demais países contrários à nação.

Seguindo a mesma lógica, a denúncia de tratados internacionais e o descumprimento das decisões das Cortes Internacionais também são atitudes costumeiras dos leaderships, assegurando o seu poder e blindando as violações dos direitos humanos contra o não povo para que não sejam alvo de questionamentos pela comunidade internacional.

Como forma de proteção da democracia, um dos pontos centrais é justamente a identificação e o fortalecimento dos atores internacionais de proteção dos direitos humanos. A criação de mecanismos de proteção internacional possibilita um controle maior de órgãos externos relativamente à atuação desmedida do populista. Ao estabelecer um sistema protetivo independente e autônomo, que não se submete às ingerências de países, a comunidade internacional fortalece o ambiente democrático interno e externo em contrapartida a interesses alheios ao Estado Democrático de Direito, decorrentes da ascensão populista e de todos seus temerários impactos.

\section{O PAPEL DO SISTEMA INTERAMERICANO DE PROTEÇÃO DOS DIREITOS HUMANOS}

A fim de compreender a prática dos atores internacionais e como reagem os populistas diante de sua atuação, voltamo-nos ao funcionamento do sistema interamericano de proteção dos direitos humanos.

A Convenção Americana é considerada o instrumento de maior importância no sistema interamericano para proteção dos direitos humanos. Os dois principais órgãos de proteção previstos pela Convenção são a Comissão Interamericana de Direitos Humanos (CIDH) e a Corte Interamericana de Direitos Humanos. Ambos os órgãos são compostos por sete membros, todos eleitos a título pessoal pela Assembleia Geral da Organização, nos termos da Convenção Americana de Direitos Humanos, em especial dos artigos 37 e 53.

A CIDH tem por principal função a promoção da observância e da proteção dos direitos humanos nas Américas. Desse modo, é competência da Comissão a realização de recomendações aos governos dos Estados-partes, prevendo a adoção de medidas adequadas para a proteção dos direitos humanos. Ainda, compete à CIDH elaborar estudos e relatórios que se mostrem necessários ao desempenho de suas atividades, e solicitar aos governos as informações que sejam relativas às medidas por eles adotadas quanto à aplicação da Convenção, submetendo um relatório anual à Assembleia Geral da Organização dos Estados Americanos. $\mathrm{Na}$ mesma linha, também compete à Comissão examinar as comunicações encaminhadas por indivíduos ou grupos, até mesmo de organizações não governamentais (ONG), que contenham denúncias de violação a direitos protegidos pela Convenção Americana.

No que diz respeito à Corte Interamericana de Direitos Humanos, constitui o órgão jurisdicional do sistema interamericano de direitos humanos dotado de competências consultiva e contenciosa. A competência consultiva compreende aquela relativa à interpretação dos próprios dispositivos da Convenção Americana e de outros instrumentos internacionais. Por 
outro lado, quanto à competência contenciosa, trata-se exclusivamente do caráter jurisdicional da Corte, referindo-se ao julgamento das controvérsias envolvendo violação a direito ou liberdade previstos pela Convenção.

Note-se que, diversamente do sistema europeu, apenas a Comissão Interamericana e os Estados-partes podem submeter um caso a julgamento pela Corte Interamericana, podendo os parentes ou representantes das vítimas tão somente submeter de forma autônoma as suas solicitações, os seus argumentos e as provas à Corte.

Importa ressaltar que a decisão emanada pela Corte tem força jurídica vinculante aos Estados-partes, devendo estes aplicar de imediato o seu conteúdo, dando efetivo cumprimento ao decidido. Em outras palavras, "se a Corte fixar uma compensação à vítima, a decisão valerá como título executivo, em conformidade com os procedimentos internos e relativos à execução de sentença desfavorável ao Estado" (PIOVESAN, 2019, p. 157).

Ademais, como explica Lois B. Sohn (apud PIOVESAN, 2019, p. 157),

A Convenção Americana de Direitos Humanos também contém cláusulas opcionais, pelas quais um Estado-parte pode aceitar a jurisdição da Corte Interamericana de Direitos Humanos, com respeito a todas as questões relacionadas à interpretação ou aplicação da Convenção. Uma vez que esta jurisdição tenha sido aceita por um Estado-parte, um caso pode ser submetido à Corte, seja pela Comissão Interamericana de Direitos Humanos, seja por um outro Estado-parte. Adicionalmente, a Corte tem ampla jurisdição para apresentar opiniões consultivas a pedido de qualquer Estado membro da Organização dos Estados Americanos ou de qualquer órgão daquela Organização.

Observa-se que, em razão da sua competência institucional, o fortalecimento do sistema interamericano de proteção dos direitos humanos é essencial para impedir qualquer tipo de ofensiva contra os direitos consagrados na Convenção Americana, sendo dever dos Estados respeitar a autonomia de atuação da Comissão e da Corte Interamericana para o adequado funcionamento de todo o sistema.

As ameaças populistas ao desempenho dos órgãos da Convenção Americana, além de representarem uma ofensa ao próprio tratado, legitimam a atuação agressiva do leadership ante a qualquer pacto anteriormente firmado, assim como a investida perante direitos previstos pelo ordenamento jurídico interno e externo. Invocar investidas em sentido oposto ao funcionamento dos órgãos da Convenção é verdadeira ameaça à estrutura jurídica e política do Estado Democrático de Direito. Desse modo, o reconhecimento da legitimidade e competência dos Tribunais Internacionais é medida que possibilita a autoproteção em uma relação de via dupla: dos Tribunais Internacionais em proteção aos Tribunais internos e estes em proteção daqueles, reconhecendo a sua jurisdição.

\section{IMPACTO DO SISTEMA INTERAMERICANO DE DIREITOS HUMANOS ANTE OS ATAQUES POPULISTAS}

Assegurar o livre-exercício do sistema interamericano é importante e necessário para a proteção dos direitos humanos nas Américas. Ao acolher a tese de que há o funcionamento de uma relação recíproca em que se reconhece as limitações mútuas dos atores domésticos e internacionais, faz-se possível salvaguardar direitos diante dos riscos de retrocessos sociais e institucionais gerados pelo populismo. 
Como visto, a Corte Interamericana empreende duas funções fundamentais no plano internacional: a primeira é o papel consultivo, ou preventivo, servindo como base para a atuação dos Estados-membros da Convenção em seu plano interno, estabelecendo uma visão autorizada ante os dispositivos controvertidos; a segunda é justamente o papel repressivo, fruto da competência contenciosa da Corte, fundando-se no julgamento das controvérsias com a devida condenação aos Estados que violaram os dispositivos da Convenção.

Transita-se, assim, ao estudo de três casos emblemáticos selecionados que marcaram a atuação da Corte Interamericana na proteção das instituições e consolidação do Estado de Direito diante das ofensivas populistas antidemocráticas.

\subsection{Tribunal Constitucional vs. Peru (2001)}

Julgado em 31 de janeiro de 2001, este caso diz respeito à destituição de três magistrados, Manuel Aguirre Roca, Guillermo Rey Terry e Delia Revoredo Marsano, do Tribunal Constitucional do Peru. Tratou-se da aplicação de uma sanção por parte do Poder Legislativo em um contexto de impeachment.

Um elemento importante dessa decisão diz respeito à tentativa de deslegitimação empregada pelo governo peruano perante a Corte Interamericana. O Peru é Estado-parte da Convenção desde 28 de julho de 1978, expressando o reconhecimento da competência contenciosa da Corte em 21 de janeiro de 1981 (IDH, 2001, par. 3). O Estado do Peru, entretanto, não apresentou nenhuma defesa nos autos, muito menos compareceu à instância em que foi citado. Em verdade, houve a tentativa do Estado de retirar a jurisdição contenciosa da Corte, ainda que sem denunciar a adesão à Convenção. A retirada foi uma evidente retaliação à interferência no plano jurídico interno do país, uma manobra para afastar a competência da Corte e evitar a apreciação do caso.

A Corte, por outro lado, declarou inadmissível a suposta retirada da jurisdição contenciosa por parte do Estado do Peru (IDH, 2001, par. 58), tendo em vista que "um Estado não pode privar um tribunal internacional, mediante ato unilateral, da competência que tenha assumido previamente" (IDH, 2001, par. 20), complementando que, além de não haver previsão na Convenção Americana, a retirada da jurisdição contenciosa da Corte deveria ter sido requerida por notificação prévia de um ano, em respeito à segurança e estabilidade jurídicas (IDH, 2001, par. 20).

Ainda, a Corte Interamericana reconheceu que o respeito aos direitos humanos constitui um limite à atividade estatal, sendo ilegal qualquer forma de exercício de poder público que viole os direitos reconhecidos pela Convenção Americana (IDH, 2001, par. 67). O próprio processo de impeachment, ainda que não seja um juízo judicial, mas, sim, político, é contemplado pela previsão das "Garantias Judiciais" contidas no artigo 8ㅇ da Convenção, de modo que toda a pessoa que for sujeita a um juízo de qualquer natureza ante um órgão estatal deverá contar com a observância de todas as garantias judiciais, mais precisamente que o órgão seja competente, independente e imparcial e que atue nos termos do procedimento legalmente previsto para o conhecimento e solução do caso (IDH, 2001, par. 77).

Ao reconhecer que o procedimento de impeachment ao qual foram submetidos os magistrados destituídos não assegurou a estes as garantias do devido processo legal e da imparcialidade do julgador, a Corte considerou que houve a violação pelo Estado do Peru às garantias judiciais das vítimas. 
De fundo, um dos pontos relevantes dessa decisão é o reconhecimento da independência dos magistrados constitucionais enquanto um dos principais componentes do princípio da separação dos Poderes, conferindo proteção e independência ao Judiciário, especialmente ao Tribunal Constitucional, fortalecendo as instituições internas e consolidando o Estado Democrático de Direito.

\subsection{Chocrón Chocrón vs. Venezuela (2011)}

O caso Chocrón Chocrón vs. Venezuela foi julgado em 10 de julho de 2011. Trata-se da destituição arbitrária de Mercedes Chocrón Chocrón, juíza de Primeira Instância Penal da Circunscrição Judicial da Área Metropolitana de Caracas, em ausência de garantias mínimas do devido processo legal, sem a devida motivação, em expressa violação aos direitos consagrados nos artigos 8 o (garantias judiciais) e 25 (proteção judicial) da Convenção Americana (IDH, 2011, par. 1-2).

No que se refere ao aspecto da independência judicial, a Corte reforçou o entendimento de que o Tribunal não é competente para definir qual o arranjo institucional mais adequado para a garantia da independência judicial. A sua competência contenciosa é restrita à análise do caso concreto em si, em que se teve a aplicação de um desenho institucional específico, verificando se ocorreram violações aos dispositivos da Convenção Americana e, em caso positivo, determinando quais são as reparações cabíveis (IDH, 2011, par. 95).

Desse modo, o alcance das garantias judiciais e da efetiva proteção judicial, no que diz respeito aos magistrados, à luz do entendimento da Corte, deve ser acompanhado com a observância do princípio da independência judicial. Sendo a independência judicial um dos objetivos principais do princípio da separação dos Poderes, a Corte reconheceu que a proteção judicial é necessária para que os integrantes do Poder Judicial não sejam acometidos por restrições indevidas em razão do exercício de suas funções por órgãos adversos, sendo este elemento basilar para a segurança do Estado Democrático de Direito (IDH, 2011, par. 97).

Ainda, seguindo a jurisprudência da própria Corte, em conformidade com os Princípios Básicos das Nações Unidas relativos à independência judicial, foram destacados três princípios essenciais para o fortalecimento das instituições judiciais e, em consequência, do Estado Democrático: a) um processo adequado de nomeação; b) a imobilidade no cargo; e c) a garantia contra pressões externas (IDH, 2011, par. 98).

Uma vez violados os dispositivos da Convenção Americana, a Corte determinou que o Estado Venezuelano incorporasse novamente a juíza a um cargo similar ao que ela desempenhava, com a mesma remuneração, benefícios e nível. Ainda mais importante, fixou o entendimento de que toda e qualquer interpretação judicial realizada pelo Estado sobre as garantias judiciais e demais direitos dos magistrados deverá ser realizada à luz da independência judicial e os seus princípios norteadores (IDH, 2011, par. 172).

\subsection{Tribunal Constitucional (Camba Campos e outros) vs. Equador (2013)}

A sentença proferida pela Corte Interamericana de Direitos Humanos, em 28 de agosto de 2013, refere-se à destituição arbitrária de oito membros do Tribunal Constitucional do Equador, mediante resolução do Congresso Nacional de 25 de novembro de 2004 (IDH, 2013, par. 1). 
Este leading case aprofundou e reforçou o entendimento da Corte Interamericana sobre a independência judicial. Ao considerar que o Estado do Equador é responsável pelos danos decorrentes da destituição arbitrária, a Corte reconheceu que o Equador tem responsabilidade quanto aos efeitos danosos ao exercício da função judicial, independência judicial e garantia da imparcialidade. Esse caso foi importante para o aprimoramento das normas sobre independência judicial, aspectos institucionais da separação dos Poderes e democracia.

Conforme apontado na sentença, a "reorganização" dos Tribunais Superiores, com nomeação de magistrados próximos ao governo e a destituição de membros contrários, ocorreu em meio à situação política de instabilidade presenciada no Equador, que, anteriormente, implicou remoção de vários presidentes e constantes modificações do texto constitucional com o objetivo de sanar a crise política. A "reorganização" teria objetivado afastar a jurisdição da Suprema Corte do Equador para anular os julgamentos criminais ante o ex-presidente Abdalá Bucaram (IDH, 2013, par. 211).

Uma vez, portanto, que os membros do Tribunal Constitucional foram destituídos a partir de uma resolução do Congresso Nacional, que não tinha competência para tanto, ou seja, mediante uma decisão sem qualquer sustento normativo, seguiu-se à ingerência do Poder Legislativo sob o Poder Judicial, desviando o poder deste último a fim de se obter o controle da função judicial por meio de diferentes procedimentos, como a destituição e os julgamentos políticos (IDH, 2013, par. 219).

Considerando que a imparcialidade judicial exige o reconhecimento das garantias judiciais, a inobservância dos elementos essenciais da democracia representativa, como o respeito aos direitos humanos e às liberdades individuais, bem como o descumprimento do princípio da separação e independência dos Poderes, estaria a implicar em verdadeira desestabilização da ordem democrática. Nesse sentido, a Corte concluiu que

a destituição de todos os membros do Tribunal Constitucional implicou uma desestabilização da ordem democrática existente nesse momento no Equador, pois houve uma ruptura na separação e independência dos poderes públicos quando foi feito um ataque às três altas Cortes do Equador na época (IDH, 2013, par. 221).

Desse modo, a Corte desempenhou papel fundamental para a proteção do Estado Democrático.

O desafio que se extrai dos casos relacionados é justamente o fortalecimento e a proteção das instituições do Estado Democrático de Direito, particularmente no que diz respeito ao acesso à justiça no sistema de proteção judicial e na independência do Poder do Judiciário, respeitando a separação e a independência entre os Poderes.

\section{CONCLUSÕES}

A crise da democracia liberal é reflexo da perda da legitimidade política das instituições representativas do Estado Democrático. Decorre de um processo avançado de deterioração da representação política acentuada pelo aprofundamento da crise econômica.

Como visto, a democracia liberal, um sistema político liberal e democrático, entendido enquanto o conjunto das instituições democráticas que transformam a vontade popular em políticas públicas e que protegem os direitos fundamentais dos indivíduos, possibilita a ascen- 
são pela via eleitoral de contramovimentos que questionam os seus próprios valores e fundamentos. A atualidade demonstra que as democracias são ameaçadas em seu próprio jogo eleitoral. Democracias também morrem pelas urnas.

Nesse cenário, em que pese seja possível o desenvolvimento de contramovimentos progressistas que defendem direitos políticos e sociais como direitos humanos, lutando contra a centralização política e econômica, fomentada pela crise da democracia liberal e pelo terreno fertilizado pela insegurança e medo popular, alimentada pelo aumento do desemprego, da desigualdade econômica-social e do fluxo migratório, também faz propagar o ideário dos contramovimentos populistas.

O processo de globalização das economias estatais e a interdependência dos mercados mundiais evidenciam a flexibilização da soberania estatal. Com isso, emergem-se as crises identitárias, favorecendo o fortalecimento de movimentos nacionalistas que lutam não contra a degeneração da democracia, mas, sim, no combate à sua existência. A globalização, aliada à crise econômica, escancarou o tripé ultranacionalista desses contramovimentos: o nacionalismo xenófobo, que se apresenta contra o não nacional, culminando na criminalização dos migrantes; o nacionalismo cultural, radioativo às identidades externas, aos costumes e às diferenças étnicas e regionais; e, por fim, o nacionalismo autoritário, refletido no repúdio aos supostos inimigos da soberania nacional.

$\mathrm{Na}$ "era dos radicalismos", os populistas apresentam as suas armas com mais facilidade. Falando em nome do povo, pelo povo e para o povo, o populista tem como suposto objetivo dar fim a todas as mazelas econômicas e sociais que afligem os nacionais, sem a intermediação das instituições - mas não quaisquer nacionais, uma vez que são os "verdadeiros" nacionais, aqueles que estão ao seu lado, os únicos identificados enquanto povo. São, portanto, antipluralistas. As únicas visões políticas aceitas são as suas. Todos os atos do populista são para o "bem do povo"; ele sabe o que querem e como querem. O leadership tem, em sua clareza pessoal, que a oposição é naturalmente contrária aos interesses populares pelo simples fato de ser oposição. A verdadeira e exclusiva moral é a sua; o único representante dessa moral é ele mesmo. Não há identitarismo maior que esse. É o populista "contra tudo o que está aí", e quem não concorda é inimigo.

Outro traço comum entre os populistas é o falacioso discurso de ódio às elites econômicas. "Somos antielitistas, antiestablishment", dizem os populistas. Nas entranhas desse discurso, todavia, esconde-se uma das condições necessárias para que o populista tenha chegado ao poder: o apoio do poderoso $1 \%$ da população, que já detém o poder político e econômico, mas que utiliza do populista para impulsionar e defender, ainda que implicitamente, os seus interesses.

As características dos movimentos populistas desembocam em medidas de enfrentamento às instituições democráticas. Tenta-se colonizar o Estado, eliminando qualquer empecilho na aplicação e no desenvolvimento de suas políticas. Uma das formas de concretizar essa colonização é justamente por meio do "clientelismo de massas", efetivando trocas de favores materiais e imateriais entre os governantes e governados, possibilitando a execução, sem questionamentos ou com pouca visibilidade dessas críticas, dos métodos mais danosos dos populistas, identificados como "legalismo discriminatório". À luz do legalismo discriminatório o não povo é reprimido e tem os seus direitos restringidos ou cortados. Converte-se o 
poder à coercibilidade, reprimindo minorias e oposicionistas com ataques às suas liberdades individuais e garantias democráticas.

Em tempos de democracia imperfeita, os primeiros ataques focam-se nos diferentes atores sociais. Os meios de comunicação, sobretudo, são alvos constantes de críticas pelos populistas. Tentam deslegitimá-los, descredibilizar as suas informações e sufocar o seu alcance popular. A independência da mídia é prejudicial aos autocratas que usam das ferramentas do próprio sistema político para permanecer no cargo e instituir suas políticas. É vital para a manutenção de qualquer regime democrático a independência midiática. Por isso, esse será o primeiro ataque do populista.

Não obstante, os ataques não se limitam aos atores sociais. Outro alvo estratégico do populista são os Poderes que fiscalizam os seus próprios atos - e sobretudo quando se trata de um poder não representativo, mas contramajoritário. O Poder Judiciário é um alvo permanente dos populistas. Aumento ou diminuição do número de magistrados, aposentadoria compulsória, destituição do cargo etc., são diversas formas de ataques. A democracia se esfalece, o autoritarismo se expande.

A partir do pós-Segunda Guerra, porém, com a arquitetura protetiva internacional dos direitos humanos, a comunidade internacional tornou-se muito mais vigilante. Atores internacionais também se tornaram preocupações dos autocratas. No contexto Sul Global, o Sistema Interamericano de Proteção dos Direitos Humanos mostra-se essencial na garantia da ordem democrática e dos direitos fundamentais. Os julgados da Corte Interamericana de Direitos Humanos demonstram que o fortalecimento da democracia passa necessariamente pela garantia da independência judicial, do princípio da separação dos Poderes e das garantias judiciais previstas na Convenção Americana.

No caso Tribunal Constitucional vs. Peru (2001), a Corte considerou que o alcance das garantias judiciais deve ser respeitado independentemente da natureza do processo ao qual o indivíduo está sendo submetido. Especificamente em relação aos magistrados, a observância das garantias judiciais é elemento central na constituição da independência judicial. Qualquer restrição ao exercício do cargo dos integrantes do Poder Judicial é afrontosa ao princípio da separação dos Poderes, de modo que, conforme amplamente foi reconhecido no caso Chocrón Chocrón vs. Venezuela (2011), para que seja assegurada a independência judicial o Estado deverá garantir um processo adequado de nomeação, a imobilidade no cargo e a garantia contra pressões externas aos magistrados. De igual modo, a destituição de membros de um Tribunal Constitucional, à luz do caso Tribunal Constitucional (Camba Campos e outros) vs. Equador (2013), de modo arbitrário e em inobservância dos preceitos já relatados, representa uma tentativa de desestabilização da ordem democrática, rompendo com a separação e independência entre os três Poderes.

Estes casos emblemáticos permitem compreender o relevante impacto do sistema interamericano e sua extraordinária contribuição para o fortalecimento dos direitos humanos, da democracia e do Estado de Direito na região, ao impor limites à atuação arbitrária e abusiva de atores populistas, que compromete a observância de direitos humanos e a própria institucionalidade democrática. 
A salvaguarda dos direitos humanos, da democracia e do Estado de Direito como plataforma de resistência aos regimes populistas, demanda a atuação de diversos atores sociais nacionais e internacionais comprometidos com os ideários democráticos.

Afinal, como advertem Steven Levitsky e Daniel Ziblatt (2018, p. 217): “Nenhum líder político isoladamente pode acabar com a democracia; nenhum líder sozinho pode resgatar uma democracia, tampouco. A democracia é um empreendimento compartilhado. Seu destino depende de todos nós".

\section{REFERÊNCIAS}

APPADURAI, Arjun. Fadiga da democracia. Trad. Débora Landsberg. In: APPADURAl, Arjun et al. A grande regressão: um debate internacional sobre os novos populismos e como enfrentá-los. 1. ed. São Paulo: Estação Liberdade, 2019. p. 19-35.

BOBBIO, Norberto; MATTEUCCI, Nicola; PASQUINO, Gianfranco. Populismo. In: Dicionário de política. Trad. Carmen C. Varriale et al. Coord. trad. João Ferreira. Rev. geral João Ferreira e Luis Guerreiro Pinto Cacais. 11. ed. Brasília: UnB, 1998. p. 980-986. Vol. 1.

CASTELLS, Manuel. Ruptura: a crise da democracia liberal. Trad. Joana Angélica d'Avila Melo. 1. ed. Rio de Janeiro: Zahar, 2018.

CIDH. Corte Interamericana de Direitos Humanos. Caso do Tribunal Constitucional vs. Peru. Mérito, reparações e custas. Sentença de 31 de janeiro de 2001. Série C № 71.

CIDH. Corte Interamericana de Direitos Humanos. Caso Chocrón Chocrón vs. Venezuela. Exceções preliminares, mérito, reparações e custas. Sentença de 10 de julho de 2011. Série C № 227.

CIDH. Corte Interamericana de Direitos Humanos. Caso do Tribunal Constitucional (Camba Campos e outros) vs. Equador. Exceções preliminares, mérito, reparações e custas. Sentença de 28 de agosto de 2013. Série C № 268. DELLA PORTA, Donatella. Política progressiva e regressiva no neoliberalismo tardio. Trad. Débora Landsberg. In: APPADURAl, Arjun et al. A grande regressão: um debate internacional sobre os novos populismos e como enfrentá-los. 1. ed. São Paulo: Estação Liberdade, 2019. p. 57-76.

FIESP. Desemprego fica em 11\% em dezembro, mas ainda atinge 11,6 milhões, diz IBGE. Disponível em: https:// www.fiesp.com.br/sietex/noticias/desemprego-fica-em-11-em-dezembro-mas-ainda-atinge-116-milhoes-dizibge/. Acesso em: 18 fev. 2020.

G1. No Brasil, $10 \%$ mais ricos ganham cerca de 17,6 vezes mais que os $40 \%$ mais pobres, aponta IBGE. Disponível em: https:/g1.globo.com/economia/noticia/2018/12/05/no-brasil-10-mais-ricos-ganham-cerca-de-176-vezesmais-que-os-40-mais-pobres-aponta-ibge.ghtml. Acesso em: 6 jan. 2020.

KRASTEV, Ivan. Futuros majoritários. Trad. Alexandre Hubner. In: APPADURAI, Arjun et al. A grande regressão: um debate internacional sobre os novos populismos e como enfrentá-los. 1. ed. São Paulo: Estação Liberdade, 2019. p. 115-133.

LEVITSKY, Steven; ZIBLATT, Daniel. Como as democracias morrem. Trad. Renato Aguiar. 1. ed. Rio de janeiro: Zahar, 2018.

MOUNK, Yascha. O povo contra a democracia: por que nossa liberdade corre perigo e como salvá-la. Trad. Cássio de Arantes Leite e Débora Landsberg. 1. ed. São Paulo: Companhia das Letras, 2019.

MÜLLER, Jan-Werner. What is Populism? Penguin: UK, 2017.

PIOVESAN, Flávia. Direitos humanos e justiça internacional: um estudo comparativo dos sistemas regionais europeu, interamericano e africano. 9. ed. rev., ampl. e atual. São Paulo: Saraiva, 2019.

ROTH, Kenneth. The Pushback Against the Populist Challenge. Human Rights Watch, 2018. Disponível em: https:// www.hrw.org/world-report/2018/pushback-against-the-populist-challenge. Acesso em: 14 jan. 2020.

ZIZEK, Slajov. A tentação populista. Trad. Alexandre Hubner. In: APPADURAI, Arjun et al. A grande regressão: um debate internacional sobre os novos populismos e como enfrentá-los. 1. ed. São Paulo: Estação Liberdade, 2019. p. 293-313. 